\title{
Sobre tempestades con remolino y plagas de langosta. Siglos XVI al XVIII en la península de Yucatán
}

\author{
María Isabel Campos Goenaga \\ CENTRO DE INVESTIGACIONES Y ESTUDIOS SUPERIORES \\ EN ANTROPOLOGÍA SOCIAL
}

La sociedad maya prehispánica y la posterior sociedad colonial fueron sociedades agrarias por lo que la no llegada de lluvias a su debido tiempo, el exceso de las mismas o la presencia de plagas como la de langosta, provocaban no sólo crisis agrícolas sino crisis de subsistencia. En este artículo se revisa y define la presencia de estos fenómenos naturales adversos durante los siglos de dominación colonial y se relacionan con el ciclo agrícola, y con su incidencia en el grupo de población indígena, debido a las características del sistema colonial, cimentado en el tributo y formas de trabajo compulsivo.

(Huracanes, plagas de langosta, hambres, Yucatán, Colonia)

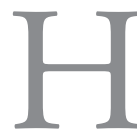

ablemos de la sociedad yucateca de los siglos XVI, XVII y XVIII. Se trata de una sociedad colonial en tanto se conforma en una situación de dominio donde se crea una relación asimétrica, dinámica y cambiante a lo largo de todo el proceso. El elemento colonizador provenía de una sociedad que se ha caracterizado como de Antiguo Régimen y que, de manera general, supone una formación económico social cuyo sistema económico se encuentra en algún momento entre la transición del feudalismo al capitalismo o en alguna de las diversas etapas de desarrollo de este último. Este elemento impuso una sociedad de las llamadas preindustriales con una economía de base agraria con baja producción, que se destina, principalmente, al autoconsumo y no al comercio; las técnicas y herramientas de trabajo que se utilizan son tradiciona-

\footnotetext{
*icgoenaga@gmail.com
} 
les, sin apenas innovaciones. Esto, junto con una deficiente infraestructura de transporte y de las redes de comunicación en general, no favorece el almacenamiento y la distribución de los productos agrícolas, en especial el trigo. Además, al estar la agricultura a merced de las condiciones climáticas, es característico que estas sociedades estén vinculadas a crisis de subsistencia.

Los mayas fueron el otro elemento que constituyó la sociedad colonial. Integraban una sociedad que desarrolló una alta cultura y en este sentido compartía características específicas con otras del Altiplano Central. La clase dirigente indígena sustentaba el poder en dos aspectos: controlando a la población y dominando el territorio y sus recursos; elementos fundamentales en una sociedad maya de agricultura extensiva y de temporal con la característica técnica de "tumba, roza y quema", que requería del control de un amplio territorio y el dominio de un sistema de milpa.

La sociedad maya prehispánica y la posterior sociedad colonial fueron sociedades agrarias por lo que la no llegada de lluvias a su debido tiempo, el exceso de las mismas o la presencia de plagas como la de langosta, provocaban no sólo crisis agrícolas sino crisis de subsistencia. En ellas, el principal producto afectado era el maíz, fuente esencial de alimento para los mayas y la población de Yucatán, en general, debido a que las condiciones del suelo yucateco no permitían el cultivo del trigo.

El objetivo de este artículo es revisar la presencia, en el espacio yucateco durante los siglos de dominación colonial, de dos de estos fenómenos naturales adversos: vientos y lluvias excesivas (donde se consideran nortes y huracanes) y plagas de langosta, y la lectura que de los mismos hacía la sociedad peninsular, así como su incidencia en una sociedad agraria. En este caso particular, la sociedad peninsular con un sistema colonial cimentado en el tributo y formas de trabajo compulsivo, por lo que cualquier crisis que impactara en la producción de alimentos, lo hacía también en el sistema económico colonial en el que se consideraba a la población maya (tributarios o no) la riqueza de la tierra. Por otro lado, en el estudio de las sociedades preindustriales es necesario establecer la conexión entre la incidencia de los fenómenos y el panorama agrícola para relacionar los 
eventos con el sistema de milpa en Yucatán, lo que en realidad constituye el riesgo de desastre.

Cabe señalar la importancia de particularizar cada uno de estos fenómenos para saber más sobre su incidencia, frecuencia y duración (siempre que las fuentes lo permitan) en las sociedades en general y yucateca en este caso. En numerosas ocasiones estos fenómenos se presentan concatenados, lo que da paso a una interpretación general de los mismos utilizando diferentes conceptos explicativos. ${ }^{1}$ A pesar de estos esfuerzos por sintetizar en un solo concepto el resultado del embate de varios fenómenos adversos en una sociedad, se necesita observar cada fenómeno por sí mismo ya que su incidencia, presencia o frecuencia impacta en tiempos y maneras específicas y la sociedad responde a ellos de maneras diferenciadas. No podemos olvidar los marcos teóricos y conceptuales que están en discusión como los conceptos de crisis bien sean de subsistencia, agrícolas o demográficos, y que comprenden este margen holístico que incluye hechos sociales, políticos, económicos y culturales en las sociedades que las padecen, en el pasado y en el presente.

\section{ESCENARIO: FÍSICO Y SOCIAL}

La provincia fisiográfica de la península de Yucatán es una llanura monótona, baja, con terrenos planos sobre una plancha endurecida calcárea llamada "roca laja”. El obispo de Yucatán, fray Francisco Toral, le escribía a Felipe II en 1565 informándole que la península era "una laja de piedra [...] tan caliza que quema las raíces de las plantas". ${ }^{2}$

${ }^{1}$ Por ejemplo, Nancy Farriss, La sociedad maya, utiliza el concepto "hambre" y engloba en este concepto todos los eventos ocurridos en un rango de tiempo. El concepto "calamidades" lo propone Paola Peniche, Tiempos aciagos, y engloba a varios eventos, en una época determinada y responde a una ideología específica, por lo que sólo se puede utilizar en ese contexto, ya que en otro, cualquiera de los elementos puede variar, en concreto el ideológico que se refiere a la percepción que del riesgo tienen las sociedades. Este significado conceptual de lo imprevisible, de la contingencia probable la sintetizó, entre otros, Beriain diciendo que para los griegos era destino, fortuna en la Edad Media y en el cristianismo providencia, Josetxo Beriain, La lucha de los dioses.

${ }^{2}$ Archivo Histórico Nacional (AHN), Diversos, Colecciones, 24, N. 73, "Carta del obispo Toral a Felipe II, 17 de octubre de 1565". López de Cogolludo dice que es "muy pedregosa", Historia de Yucatán, p. 171. 
En el sureste de Campeche y sureste de Quintana Roo son comunes los terrenos planos de suelos muy arcillosos, originalmente lechos de antiguas lagunas costeras. Existen ciertas ondulaciones a manera de cerros bajos en la colindancia con el Petén, al sur y una cordillera o cadena de lomas bajas conocida como la "sierrita Puuc" o de Ticul, corre en forma irregular hacia el oriente, desde Maxcanú hasta Peto, desde el Golfo de México hacia el Caribe.

La naturaleza caliza del suelo hace que el agua de las precipitaciones pluviales se filtre con rapidez a mantos subterráneos y forme depósitos naturales llamados cenotes; que se carezca de ríos en la parte norte, pero si existan en el sur donde la llanura calcárea desaparece. López de Cogolludo señalaba que en esta tierra "no corren ríos por la superficie de ella; pero por señales que se han visto es cierto que corren por lo interior muy copiosos". ${ }^{3}$

Al ubicar la península yucateca en el espacio terrestre, se pueden conocer los rasgos físicos que la caracterizan como, por ejemplo, la reproducción cíclica de determinados tipos de tiempo, lo que se conoce como su clima: ${ }^{4}$ temperaturas, precipitaciones, vientos y humedad que varían en las diferentes regiones de la Tierra. La península de Yucatán está situada al norte del Ecuador y se caracteriza por un clima tropical con estación de lluvias muy marcada y sequía durante el invierno. Las lluvias son más abundantes en el sur y menos en el norte y en las partes centrales. Una particularidad que se deriva de su posición entre el trópico de Cáncer y el Ecuador, es que se encuentra en la zona del hemisferio norte, en el occidente del planeta, donde se originan los huracanes. Esta situación geográfica y la característica morfología de la península yucateca, la convierten en un área de incidencia frecuente de huracanes, tempestades, temporales y nortes, fenómenos climatológicos que aun hoy en día tienen gran intensidad y que desde tiempos remotos causaban gran inquietud a sus pobladores. El exceso o la falta de lluvias, podían (y

${ }^{3}$ López de Cogolludo, Historia de Yucatán, p. 171.

${ }^{4}$ Según Jorge Olcina Cantos y Javier Martín Vide "el clima es en sí historia, resumen y devenir de acontecimientos de la atmósfera considerados durante un periodo de tiempo de al menos varias décadas -tres aconseja oficialmente la Organización Meteorológica Mundial-", La influencia de clima, p. 10 
todavía pueden) provocar la pérdida total o parcial de cosechas. Otro fenómeno presente en el panorama agrícola de la península, hasta la fecha, es la langosta que en forma de constantes plagas es una gran amenaza para los sembradíos.

En cuanto al espacio social, podemos definirlo como el de una sociedad inmersa en una dominación colonial, obsoleta e insuficiente con su régimen basado, principalmente en la institución de la encomienda hasta que en 1785 se decretó su incorporación a la Corona, ${ }^{5}$ los repartimientos y, en consecuencia, en un sistema tributario que se sustentaba en una parte mayoritaria de la población, la indígena, que a su vez era controlada por la minoría no indígena.

Para algunos autores, el sistema colonial instituido en Yucatán tenía como principal factor estructural el establecimiento de un pacto social colonial entre dos sociedades con culturas diferentes, pero con ciertas similitudes en el aspecto social (elementos humanos, entorno material, estructuras social y económica, así como los componentes económicos, sociales, etcétera), que se incluyó en la negociación colonial, en el pacto social o pacto colonial. ${ }^{6}$ Fue un pacto asimétrico y dinámico que se estableció entre los distintos actores sociales que compartían un espacio de dominación colonial. Por un lado estaba la presencia y dominación espańola que se reflejaba en el aparato administrativo de dominación colonial, sustentada en la utilización de la fuerza de trabajo indígena socialmente organizada, que era la encargada de mantener la sociedad colonial y entregar los excedentes de su producción. Por otro, sobre las repúblicas de indios recaía el tributo, el trabajo y el servicio. Los términos del pacto colonial estaban establecidos en "la entrega de grandes cantidades de excedente económico y trabajo directo" y a cambio conservarían los "espacios de autonomía cultural" y la perspectiva de controlar los "recursos básicos, fundamentalmente la tierra”. Así, la explotación "de los montes, de la tierra de cultivo y del agua, los

5 "Incorporación a la Real Corona de las encomiendas de la provincia de Yucatán", pp. 591-675.

${ }^{6}$ Bracamonte y Solís consideran que este pacto no es estático e identifican cinco etapas contextualizadas en distintos momentos de la realidad colonial. Pedro Bracamonte y Gabriela Solís, Espacio mayas, pp. 50-54. 
tres recursos básicos de la subsistencia indígena", 7 quedaron en sus manos y por tanto, la forma de explotación agrícola.

La fuerza de trabajo indígena organizada, controlada por los caciques y utilizada mediante la compulsión por los españoles era la que proporcionaba, excedentes económicos que podían mantener a toda la sociedad. Entonces, uno de los componentes principales de este sistema era la población indígena, y sobre todo en su calidad de tributaria, por lo que podemos decir que la república de españoles dependía de la de indios en los aspectos fundamentales del sistema. Así, cualquier evento que supusiera un cambio en la población maya y en la población tributaria, afectaba profundamente la base del sistema y abría camino a posibles crisis que podían minar la estructura del mismo.

\section{Sobre VIENTOS Y LLUVIAS EXCESIVAS}

En esta categoría se incluyen los principales fenómenos meteorológicos de carácter estacional que afectan a la península yucateca: en verano e invierno aparecen los nortes y los frentes fríos; los meses de abril y mayo representan un periodo muy seco; a partir de mayo y hasta octubre, la presencia de ondas tropicales con gran potencial de humedad caracterizan una época de lluvias de tipo tropical y, finalmente, la temporada de huracanes abarca de junio a noviembre.

Fue precisamente el carácter estacional de estos fenómenos lo que llamó la atención de los que, por obligación o por gusto, se dedicaron a describir los nuevos territorios. No todos los cronistas coinciden pero, un mes más o menos, hay un cierto consenso. Para el oidor Tomás López Medel formaban un todo, climatológicamente hablando, Nueva España, Guatemala, Nicaragua, Honduras, Yucatán, las islas de La Española, Cuba, Jamaica etcétera, y toda la costa "desde Santa Marta hasta Cartagena”. Para él, el invierno y las lluvias iban de la mano desde principios de mayo hasta octubre, las lluvias eran diarias "de mediodía para abajo" y sólo dejaba de llover en el veranillo de San Juan ${ }^{8}$ que duraba veinte días. Desde octubre

${ }^{7}$ Pedro Bracamonte y Gabriela Solís, Espacios mayas, p. 43.

${ }^{8}$ Es un corto periodo seco en plena estación de lluvias alrededor del día de san Juan Bautista, el 24 de junio. En la tradición castellana existe el "veranillo de san Miguel” (29 
hasta mayo del ańo siguiente, "todo es serenidad y sin algunas aguas" excepto "algunos aguaceros" que de manera ocasional caían "vueltas de Navidad".

El franciscano Diego de Landa decía lo mismo, pero de manera diferente: el invierno comenzaba en San Francisco y terminaba a fines de marzo, tiempo en el que "corren los nortes". A fines de enero y principios de febrero había "un veranillo de recios soles" y sólo llovía "a las entradas de las lunas". Las lluvias comenzaban en abril y terminaban en septiembre, época que aprovechaban los mayas para sembrar "todas sus cosas" y maduraban a pesar de la constante lluvia. ${ }^{10}$ "Las aguas que dan nutrimento a la tierra son las que del cielo provee Dios cada año", comienzan por mayo y su eficiencia dura cuatro meses, hasta fin de agosto. Esos meses son la clave para "el maíz, ají y frijoles y algodón, y según vienen las aguas, pocas o muchas, con orden o sin él, sí sucede la cosecha, porque en faltando el agua, a causa de tener la tierra poca humedad, luego se seca". ${ }^{11}$

En cuanto al viento, los que llegan del suroeste, noroeste o norte entre septiembre y febrero, "hacen gran mudanza en la gente natural y española $[. .$.$] y son algunos años tan violentos que derriban casas de$ indios y arrancan de raíz árboles muy grandes". ${ }^{12}$ López Medel observa que los nortes no solo "reinan" en Yucatán, sino que también lo hacen en Honduras, en las islas y en la costa de Nueva España. Se presentan desde "septiembre hasta mayo, y esto es muy ordinario, que es el verano de por ahí, y causan grandes polvaredas no poco enojosas, y suelen $[\ldots]$ hacer grandes estragos en la mar". En invierno y en época de lluvias, sopla "el contrario viento [con el que] suele llover en aquellas provincias". ${ }^{13}$ López de Cogolludo coincide con Landa en que "desde octubre a marzo corren Nortes" y refrescan la tierra. ${ }^{14}$

de septiembre) que dice el refrán "faltará muy rara vez", y en algunos lugares existe la creencia de que marca el inicio del otońo. Este veranillo se llama canícula.

${ }^{9}$ Tomás López Medel, De los tres elementos, p. 24.

${ }^{10}$ Diego de Landa, Relación de las cosas, p. 4.

${ }^{11}$ Relaciones Histórico-geográficas de la Gobernación de Yucatán (en adelante RHGY), I, p. 69.

${ }^{12}$ RHGY, I, pp. 69-70.

${ }^{13}$ Tomás López Medel, De los tres elementos, p. 30.

${ }^{14}$ Diego López de Cogolludo, Historia de Yucatán, p. 171. 
Si los vientos aparecen a finales de julio y agosto, "derriban y quiebran los maizales, de que redundan algunos ańos grandes hambres". Aunque la fuente en esta última descripción se refiera a los vientos, bien pudiera tratarse de una tormenta tropical o un huracán por lo meses en que acontece, ya que la temporada del Atlántico se inicia entre mediados de mayo y primeros de junio, y finaliza en octubre aunque se puede alargar a noviembre.

\section{Huracanes}

Los huracanes son grandes tormentas tropicales giratorias que se caracterizan por sus arrasadores vientos y lluvias torrenciales, y están constituidos por vientos y nubes que forman una espiral que gira en torno a un centro común al que se le llama "ojo” del huracán.

Los huracanes, "tempestades con remolino", 15 eran conocidos por mayas y otros grupos de la zona caribeña. Huracán es una palabra de origen taíno y se revela como una presencia constante en los modos de vida de las culturas antillanas y caribeńas: Juracan era el término con que los taínos designaban al dios del mal, destructor; los indios caribes de las Antillas lo llamaban Aracan, Urican y Huiranyucan, que significaba viento poderoso y viento fuerte; los indios galibi de la Guyana francesa y holandesa, usaban la palabra hyroacan para los demonios. Fernando Ortiz dice que al dios de las tormentas Huracán también se le conocía con los nombres indígenas Guabancex, Maboya y Jurakan, y era la deidad más importante en el área caribeña durante la época prehispánica; además tenía una representación iconográfica circular y cruciforme que se hace presente también en el área mesoamericana.

A la ciudad totonaca de El Tajín se la consideró como la "Ciudad Sagrada de Huracán”, dios de la tempestad y de los nortes. Huracán significa tempestad, es el equivalente a El Tajín o Trueno Viejo. Era el dios de los fenómenos tempestuosos buenos o malos, el regulador de las estaciones, de la agricultura y la fecundidad en general: Huracán (“Uno pierna”) era dios de los vientos y la tem-

${ }^{15}$ Antonio Mendíz Bolio, El libro del Chilam Balam, p. 108. 
pestad, y la lluvia, el rayo y el trueno eran sus mensajeros. ${ }^{16}$ En el Popol Vuh aparece el dios primordial de la creación, el "corazón del cielo" de los mayas quichés, y dice

entonces dispusieron la creación y crecimiento de los árboles y los bejucos y el nacimiento de la vida y la creación del hombre. Se dispuso así en las tinieblas y en la noche por Corazón del Cielo, que se llama Huracán.

El primero se llama Cuculhá Huracán. El segundo es Chipi-Caculhá. El tercero es Raxa-Caculhá. Y esos tres son el Corazón del Cielo. ${ }^{17}$

Las sociedades mesoamericanas identificaron algunos fenómenos naturales que incluyeron en sus mitos y creencias sobre los orígenes, creación o destrucción del cosmos, donde distintas deidades tienen el control de estas fuerzas (viento, agua, fuego). Los mayas de la actualidad tienen tradiciones, mitos, leyendas o explicaciones que son puntos de referencia e interpretación de los eventos relacionados con el clima. Explican los huracanes como manifestaciones de conflictos celestiales cuyos efectos tienen importantes consecuencias naturales, sociales y humanas. En los años ochenta, Michel Bocarn registró, en el este de la península yucateca, una descripción sobre la naturaleza del huracán: el que un sistema ciclónico se aproxime o se aleje de la costa tiene que ver con un enfrentamiento entre el chac malo, el destructor, con malignas intenciones para los hombres y su medio ambiente, y el chac bueno, el protector, con benévolas intenciones para los hombres y el medio ambiente:

las manifestaciones físicas del huracán, en especial la alta velocidad de los vientos, son producto (el sonido y la furia) de una titánica batalla cósmica entre las fuerzas del bien y del mal. La intensidad de las lluvias es producto

${ }^{16}$ Román Piña Chan y Patricia Castillo Peña, Tajín.

${ }^{17}$ Popol Vuh, p. 86. Según Adrián Recinos el texto se refiere a Huracán, una pierna; Caculhá Huracán, rayo de una pierna, el relámpago; Chipi Caculhá, rayo pequeño; Raxa Cuculhá, el relámpago o el trueno. Otras interpretaciones dicen que el texto revela las cuatro manifestaciones de uno de los sostenedores del cielo: Huracán y sus hermanos; él mismo como el huracán atmosférico, el Cuculhá Huracán o el rayo, el Cipi Cuculhá o trueno y el RaXá Cuculhá o rayo de color azul. 
de la energía gastada, fue el "sudor de los dioses", y el relativo grado de destrucción (tormenta oleaje, inundaciones, destrucción de los asentamientos, cultivos, flora y fauna) se convierte en una indicación de los logros del chac malo, mientras que aspectos positivos (supervivencia de los ambientes naturales y humanos, aumento de lluvias en áreas periféricas del centro de actividad de la tormenta) están asociados con el chac bueno. Los periodos o temporadas de sequía post-huracán suceden porque el buen chac utilizó mucha energía en el combate celestial y puede necesitar un largo periodo de recuperación. ${ }^{18}$

Investigaciones recientes sobre el desarrollo de la civilización maya y sus ciudades de arquitectura monumental a las que se asociaba una numerosa población, apuntan a que los mayas habían conseguido una adaptación más exitosa de lo que se creía al entorno de la selva tropical. En este ecosistema de selva tropical, los mayas desarrollaron su paradigma ecológico. Barrera Marín dice que hay indicios para suponer que la selva no sólo representaba un medio que debía ser destruido para obtener tierras de cultivo y extraer madera, sino que también se la consideraba "un recurso capaz de ser sometido inteligentemente a prácticas de conservación, de modificación y de aprovechamiento múltiple". ${ }^{19}$ Es por ello que las tormentas tropicales en general y los huracanes en especial, tuvieron que ser tomados en cuenta por los mayas prehispánicos para su adaptación a la selva de la península yucateca.

Herman W. Konrad analizó las tormentas tropicales y huracanes en relación con las prácticas de subsistencia de los mayas peninsulares y los consideró, a la luz de textos prehispánicos, coloniales y contemporáneos, uno de los rasgos que integran la cosmovisión y el paradigma ecológico prehispánico. Es más, sugiere que para analizar el declive de la civilización maya, no sólo debe hacerse a partir de los factores de desarrollo político, patrones de asentamiento, migraciones, estabilidad demográfica, guerra y comercio, sino que también debe tomarse en cuenta la efectividad en la adaptación a los efectos

${ }^{18}$ Herman W. Konrad, "Fallout of the wars of the chacs", p. 321.

${ }^{19}$ Alfredo Barrera Marín, "El manejo de las selvas por los mayas", pp. 47-61. 
ecológicos producidos por las tormentas tropicales y huracanes, ya que podría aportar luz para determinar el éxito de las estrategias de subsistencia de los mayas prehispánicos. La exposición a los efectos de las manifestaciones de la naturaleza marcó la organización social de los mayas. Konrad acuña el concepto de ecological stress que se produce por el impacto destructivo para el hábitat de los fenómenos que suelen acompañar a los huracanes, que precisamente son los factores de dicho stress ecológico. Este tipo de tensión establece las estrategias que inciden en la subsistencia del grupo y que están directamente relacionadas con los aspectos económicos, políticos y sociales de los procesos de adaptación de los mayas. ${ }^{20}$

Para los espańoles, el huracán era una manifestación desconocida de la naturaleza a la que adjudicaron un significado divino que sancionaba el comportamiento humano. Ante el desconocimiento del fenómeno, empezaron a definirlo y a buscar causas y consecuencias del mismo. Fueron los cronistas de Indias los que se interesaron en dar a conocer esta expresión violenta, intensa y peligrosa de la naturaleza. Las Casas se refiere al huracán como "de las más terribles tormentas que se cree haber en todos los mares del mundo, son las que por estos mares destas islas y tierra firme suele hacer" porque son "grandes tempestades por la mar y por la tierra, que no dejan cosa que no destruyan y echen a perder, naos en la mar y las heredades y edificios en la tierra". ${ }^{21}$ Gonzalo Fernández de Oviedo describe de "oídas" los huracanes que impactaron en 1508 y 1509 a La Española; no obstante, si presenció el de 1545. Escribe que "Huracán, en lengua desta isla, quiere decir propiamente tormenta o tempestad muy excesiva; porque, en efecto, no es otra cosa sino grandísimo viento e grandísima y excesiva lluvia, todo junto o cualquiera cosa destas por sí". 22

Tomás López Medel, utiliza los recursos científicos de que dispone y asegura que un "buracan [sic] es un concurso y contraste de diversos y contrarios vientos”, que son vientos extraordinarios y

${ }^{20}$ Herman W. Konrad, “Caribbean Tropical Storms”, pp. 98-130.

${ }^{21}$ Bartolomé de Las Casas, Apologética Historia de las Indias, cap. LXIX y cap. XXXIII.

${ }^{22}$ Gonzalo Fernández de Oviedo, Historia general y natural de las Indias, libro IV, cap. III. 
remolinos que en latín llaman "vortágines". También intenta explicar su origen y afirma que ocurren cuando de "diversas y contrarias partes concurren muchos y diversos vientos en una competencia y lucha" que en ocasiones acaban en grandes tempestades, unas veces solo de vientos y otras veces mezclados con lluvias "grandes aguas y granizos". La fuerza y furia del huracán dura "por espacio de 24 horas, hasta que ha discurrido por todos los rumbos y grados de su sphera". Sobre su frecuencia, comenta que "suelen acudir muchas veces, a lo menos pocos ańos se pasan que no se ve uno o dos en aquellas islas", y las áreas que afectan son las islas en general y "muchas veces en La Española y por toda la costa de Yucatán, hacia la Nueva España”. Según sabe, los únicos que tenían "práctica y experiencia” para prevenir su llegada eran los animales, "especialmente el ganado vacuno, que muchas horas antes que venga le sienten y, barruntando la tempestad, es cosa maravillosa como se previenen, bajándose de los altos a los bajos y poniéndose en lugares adonde, por lo pasado, saben que estarán más seguros". ${ }^{23}$ Los hombres podían prepararse al impacto del huracán siempre y cuando reconocieran el instinto de los animales y tomasen las providencias necesarias. El oidor describió el impacto de un huracán en la península yucateca y Veracruz a principios de septiembre del año $1552:^{24}$

Estando yo en la provincia de Yucatán el anno de 1551, en la visita de aquella provincia, primero día de septiembre, vino un buracán en toda aquella costa y en la de Veracruz que, con ser la tierra de Yucatán muy llana y baja y muy cercada de montes, derribó infinidad de árboles y asoló y echó por tierra todos los maíces, de suerte que hubo necesidad de tornarse a sembrar aquel año. Y escribióseme dende el puerto de Veracruz entonces que no había quedado navío entero en el puerto, y que había sido tan

${ }^{23}$ Tomás López Medel, De los tres elementos, pp. 32-33.

${ }^{24}$ Fue oidor de la Audiencia de los Confines que estuvo como visitador en Yucatán del 13 de junio de 1552 hasta 1553 . Así, el año en que pudo ser testigo del huracán sería 1552 y no 1551 como él escribe. Los efectos de este fenómeno se dejaron sentir en un amplio espacio del territorio nacional, que como en la actualidad no se limita a la zona de impacto. Al parecer, los actuales estados de Tlaxcala, Puebla e Hidalgo sufrieron las secuelas, Virginia García Acosta, "Una vista al pasado", p. 9; García Acosta et al., Desastres agrícolas en México, pp. 109 y ss. 
bravo por allá que arrincó dos vigas grandes que tenían por campanario los vecinos del puerto y, juntamente con la campana-que afirmaban ser de más de tres arrobas-, habérselas llevado por la tierra adentro más de media legua. Ansí que cierto se pasan muchos trabajos cuando vienen esos vientos y furias de Naturaleza. ${ }^{25}$

La narración refleja lo violento y destructivo del fenómeno con árboles derribados y el arrastre de una campana de iglesia, de cierto peso, tierra adentro. En cuanto a la agricultura, Landa cuenta que acabó con la caza que formaba parte del sustento del maya, así como con las milpas, de manera que hubo que hacer una resiembra. Los árboles caídos y el material con que construían las casas, paja u hojas de palma, favorecía la expansión de los incendios. ${ }^{26}$ Konrad relaciona estas secuelas de los huracanes con el paradigma ecológico de los mayas porque la pérdida de la cubierta forestal, tiene importantes implicaciones ecológicas no sólo en el proceso de renovación del mismo o en los incendios forestales provocados por los escombros del suelo; más importante aún, las tiene para la propuesta de paradigma ecológico porque "el impacto de los huracanes en selvas se convierte en una versión natural, en gran escala del sistema de roza, tumba y quema de la preparación para la siembra". Por ello, después de que los huracanes destruyesen algunas áreas selváticas, las utilizaron para sembrar de manera extensiva "donde sus chacs habían despejado la selva". ${ }^{27}$

Entonces, la concepción sobre huracanes difiere entre mayas y espańoles: para los mayas eran parte integral de su cultura y cotidianidad como elementos importantes del paradigma ecológico que sustenta a esta sociedad; para los castellanos era un elemento ajeno a su cultura que ponía en peligro su existencia vital y material, sobre el que intentaban hallar explicaciones de sus orígenes y causas, todas ellas encaminadas hacia argumentos de corte divino que también

${ }^{25}$ Tomás López Medel, De los tres elementos, p. 33. Otra descripción proviene de Landa y puede verse en María Isabel Campos, "Cuando los dioses estaban enojados".

${ }^{26}$ Diego de Landa, Relación de las cosas, p. 34.

${ }^{27}$ Herman W. Konrad, "Caribbean Tropical Storms”. Según comunicación de milperos de Chumpon a Konrad. 
sancionaba las conductas. López Medel relaciona la frecuencia y violencia de los huracanes con la evangelización y las idolatrías:

antes que se descubriesen las Indias, estando los naturales de ellas en medio de la tiniebla de su idolatría, se averigua que eran más continuos y mucho más violentos y recios estos buracanes, sin comparación, y que, después que se puso Sacramento en la isla Espańola y en las demás, se tiene por experiencia que suceden muchas menos veces estos vientos que de antes y más templados. ${ }^{28}$

No es posible saber cuántos huracanes, temporales, nortes, tempestades etcétera, impactaron en Yucatán durante los años coloniales, dónde y en qué fecha lo hicieron. Encontrar referencias sobre ellos en las fuentes históricas es un trabajo de lectura y análisis lento, minucioso. No obstante se puede elaborar un cuadro con los registros obtenidos de la documentación consultada hasta la fecha (véase cuadro 1), ${ }^{29}$ en el que podemos observar un promedio de, al menos, tres impactos de huracanes para cada siglo entre el xvi y el xvIII. Las fechas o la época del impacto coinciden con la temporada de huracanes del Atlántico, igual que la época de los nortes que llegaban en invierno (enero a abril) y eran más intensos en los meses de febrero y marzo.

Cuadro 1. Huracanes, nortes, temporales, lluvias excesivas o abundantes en Yucatán. Siglos XV, XVI, XVII, XVIII y XIX

\begin{tabular}{llll}
\hline Fecha & Mes/Estación & Lugar de impacto & Suceso \\
\hline $\begin{array}{l}1464 \\
\text { (circa) }\end{array}$ & $\begin{array}{l}\text { Octubre } \\
\text { Noviembre }\end{array}$ & Yucatán & Huracán \\
1517 & Febrero & Yucatán: de Cuba a Yucatán & Tormenta (Norte) \\
1517 & Marzo & Yucatán: Campeche (costa) & Tormenta (Norte) \\
1552 & $1^{\text {o }}$ & Yucatán & Huracán \\
& Septiembre & Veracruz &
\end{tabular}

${ }^{28}$ Tomás López Medel, De los tres elementos, pp. 33-34.

${ }^{29}$ Ante nuevos documentos o lecturas de los mismos, el cuadro puede variar. Este comentario se aplica a todas las tablas que contiene este artículo. 
Cuadro 1. Huracanes, nortes, temporales, lluvias excesivas o abundantes en Yucatán. Siglos XV, XVI, XVII, XVIII y XIX (continuación)

\begin{tabular}{|c|c|c|c|}
\hline Fecha & Mes/Estación & Lugar de impacto & Suceso \\
\hline 1561 (circa) & & $\begin{array}{l}\text { Yucatán: Sotuta, Kanchunup, } \\
\text { Mopilá, Sahcabá, Usil, Tibolón. }\end{array}$ & Huracán \\
\hline 1568 & Verano & Yucatán & Huracán \\
\hline 1579 & Invierno & Yucatán: Mérida & Nortes \\
\hline 1611 & & Yucatán & Huracán \\
\hline 1614 & 31 agosto & $\begin{array}{l}\text { Yucatán } \\
\text { Isla Cumto y Cabo Catoche }\end{array}$ & $\begin{array}{l}\text { Lluvias abundantes } \\
\text { Temporal } \\
\text { (Huracán) }\end{array}$ \\
\hline 1623 & & Yucatán & $\begin{array}{l}\text { Temporal, } \\
\text { Lluvias excesivas } \\
\text { Inundación }\end{array}$ \\
\hline 1628 & & Yucatán & Lluvias abundantes \\
\hline 1648 & & Yucatán & Inundación \\
\hline 1654 & Octubre & Yucatán & $\begin{array}{l}\text { Gran tempestad } \\
\text { (Huracán) } \\
\text { Lluvias abundantes }\end{array}$ \\
\hline 1692 & & Yucatán & Huracán \\
\hline $1744-46$ & & Yucatán & Lluvias excesivas \\
\hline 1766 & 18 agosto & Yucatán & Huracán \\
\hline 1767 & & Yucatán & Huracán \\
\hline 1772 & 4 septiembre & Yucatán & Huracán \\
\hline 1807 & & Yucatán & Huracán \\
\hline
\end{tabular}

Fuentes: Landa, Relación de las cosas de Yucatán; López de Cogolludo, Historia de Yucatán, López Medel, De los tres elementos; Scholes y Adams, Don Diego Quijada Alcalde Mayor de Yucatán; Relaciones histórico geográficas; Pedro Sánchez de Aguilar, Tratado contra Idolorum cultores; Molina Hubbe, Las hambres de Yucatán; Chilam Balám; AGI, México, 369, "Obispo a la Corona, 18 abril de 1693"; AGI, México 3057, "Testimonio sobre la falta de tributarios, 1775"; AGI, México, 1975, "Comercio de Campeche a la Corona, 21 enero de 1808". 


\section{Plagas de langosta}

El hombre ha sufrido plagas de langosta ${ }^{30}$ desde siempre y cuando se hizo sedentario y comenzó a cultivar la tierra, las padeció todavía más. Forman parte del sustrato mítico de la humanidad: la octava plaga con la que se castigó a Egipto fue de langosta, ${ }^{31}$ el Corán ${ }^{32}$ también la registra y, saak ${ }^{33}$ está presente en las profecías mayas para el katún 13 Ahau del Chilam Balam de Maní.

En España la langosta gozó de un clima y hábitat ideal para su desarrollo. En la península ibérica hay varias zonas donde se reproducen y desde las que se puede originar una plaga de la langosta Dociostaurus maroccanus: los Monegros (entre Zaragoza y Huesca), La Serena (Badajoz), los Llanos (Cáceres) y el valle de la Alcudia (Ciudad Real). ${ }^{34}$ La parte de Albacete y el oriente de la Mancha son los lugares en que existe otra especie que también afecta a la península: Calliptamus italicus.

En la península de Yucatán la especie endémica es la langosta centroamericana, Schistocerca piceifrons piceifrons, ${ }^{35}$ que habita el sureste de México hasta Costa Rica. Las zonas donde se reproduce de

${ }^{30}$ Nombre común que se le da a diversas especies de insectos ortópteros de la familia locústidos antes acrídidos. Son especies de cuerpo alargado, patas posteriores adaptadas al salto y antenas cortas. Se alimentan de vegetales y viven en países cálidos. Presentan dos fases: solitaria y gregaria, momento en el que forman grandes masas migratorias que se desplazan juntas destruyendo a su paso toda la vegetación.

31 "Cubrieron toda la superficie des país hasta oscurecer la tierra; comieron toda la hierba del país y todos los frutos de los árboles que el granizo había dejado; no quedó nada verde ni en los árboles ni en las hierbas del campo en toda la tierra de Egipto", Éxodo, $10: 15$.

32 Sura vir. El Araf. 130. "Entonces enviamos contra ellos la inundación, la langosta, la miseria, las ranas y la sangre, signos evidentes; pero ellos se hincharon de orgullo, pues eran criminales".

${ }^{33}$ Langosta, chapulín.

${ }^{34}$ Antonio Buj Buj, "Les plagues de llagosta”, pp. 5-19.

${ }^{35}$ Tiene tres fases de desarrollo: huevo, ninfa e imago o adulto. El imago y el adulto se diferencian en que el primero, aunque vuela, tiene los órganos sexuales inmaduros, mientras que el adulto es un imago con órganos sexuales funcionales. Otra característica es que cuando se da el cambio de la fase solitaria a la fase gregaria (y viceversa, esta especie centroamericana puede revertir el proceso) cambia de aspecto (tamańo, color, fisiología, comportamiento). Ludivina Barrientos Lozano et al., Manual técnico sobre la langosta voladora, pp. 24-47. 
manera permanente e inicia la fase de gregarización son Yucatán (península), la costa del Pacífico en Guatemala y zonas cercanas al Golfo de Fonseca en El Salvador, Honduras y Nicaragua. Cuando se dan unas condiciones meteorológicas singulares y se vinculan de forma positiva, se genera su propagación incontrolable al entrar en su fase gregaria, y entonces alcanzan lugares más fríos y secos y de mayor altitud. En Yucatán esta zona corresponde al área henequenera en el noroeste de la península, con terrenos descubiertos, poca cobertura vegetal y cercana a las zonas de cultivo. Esta langosta tiene dos generaciones por ańo lo que explica la constante presencia de langostas en la zona. ${ }^{36}$ El maíz es uno de los cultivos al que más ataca, pero no es el único, también gusta de la soya, frijol, ajonjolí, sorgo, cacahuate, algodón, caña de azúcar, plátano, diferentes frutales y ocasionalmente arroz, que al estar cubierto por agua se dificulta su destrucción.

Para castellanos y mayas, la langosta era un viejo conocido, protagonista de episodios peligrosos para sus sociedades de carácter agrícola, por lo que las plagas significaban como mínimo la pérdida de las cosechas, pero tenían distintos modos y formas de aprehender las plagas de este insecto, asimilarlas y combatirlas. Con la dominación colonial se impusieron las formas castellanas aunque cada grupo mantuvo sus propias concepciones. ${ }^{37}$

Felipe II promulgó en 1593 una ley sobre la "Obligación de las justicias ordinarias a hacer matar la langosta a costa de los Concejos" y junto a otras que se adicionaron posteriormente se conformó el Libro vII, Título xxxi de la Novísima Recopilación de las Leyes de España ${ }^{38}$

${ }^{36}$ Ciclo reproductivo: en el periodo de seca, entre diciembre y mayo, están como imagos; al inicio de las lluvias, entre mayo y junio, adquieren la madurez sexual e inicia el primer ciclo reproductor. A los 15 o 20 días de depositar los huevos surgen las ninfas de primera generación (junio - julio). Por su parte, los adultos de la primera generación maduran sexualmente en un período de 25 a 35 . En esta etapa son muy voraces y en forma de enormes mangas arrasan con los cultivos. El ciclo reproductivo de estos adultos comienza en septiembre y octubre, por lo que las ninfas de segunda generación aparecen entre septiembre y diciembre. De ahí se transforma en adulto imago y después de 5 o 6 meses alcanzan la madurez sexual, que coincide con el inicio de las lluvias del ciclo siguiente. Enrique Garza Urbina, "La langosta schistocerca piceifrons piceifrons".

${ }^{37}$ Véase María Isabel Campos, "Conciencia mágica”.

${ }^{38} \mathrm{La}$ adiciones fueron de Felipe V en 1723, que es la Ley vı; en 1755 una instrucción al Consejo que ratificaría Carlos IV en 1783 y en 1804 y que son las leyes viI, viII y IX. 
que lleva por título "De la extinción de animales nocivos y la langosta”. Algunas de estas disposiciones pasaron a América, como la ley sobre "Que se pueda hacer repartimiento entre eclesiásticos, seculares y Real Hacienda para extinguir la langosta", que se justifica porque "el beneficio es común y la causa pública” ${ }^{39}$ Esta legislación incluía reglas para la extinción de la langosta en sus tres estados de desarrollo: de aovación o canuto, de feto o mosquito y adulta o saltadora. De acuerdo al estado de desarrollo de la langosta variarán los métodos. Así, la forma natural de acabar con la langosta comprendía diversas técnicas como limpiar y cortar la hierba de los campos, podar los árboles pero untando las herramientas con sebo de oso o con ajos machacados y desechos en aceite. Otro procedimiento consistía en conducir manadas de cerdos a los campos para que fuera destruida y aniquilada, o arar y romper las partes donde estaba cuando se encontraba en la fase de aovación o canuto; después se amontonaba y se le prendía fuego. Todos los vecinos mayores de 12 años tenían la obligación de recoger la langosta y se les pagaba un tanto por langosta recogida. También la perseguían y exterminaban grajos, tordos, puercos, pavos y cuervos. Se sabía que la langosta es sensible a las lluvias y al rocío porque cuando se humedecen sus alas pierden elasticidad y les impide volar; a las bajas temperaturas; al agua de mares, lagos, ríos etcétera, que las atraen y se ahogan; al humo producido por la combustión de materiales como paja húmeda o leña verde, y a los truenos o ruidos fuertes.

Los registros de la época colonial sobre plagas de langosta en Yucatán son abundantes. La plaga se presentaba en ańos consecutivos por las dos generaciones anuales que la mantienen en estado latente. López Medel afirmaba que a la provincia de Yucatán llegaba

De esta Novísima Recopilación, hay que destacar la Ley vir que establece las "Reglas para la extinción de la langosta en sus tres estados; y modo de repartir los gastos que se hicieren en este trabajo", y supone ya un amplio conocimiento de las fases de desarrollo y de reproducción de la langosta. Carlos IV ordenó esta recopilación que se promulgó en 1805.

${ }^{39}$ Ley v del Libro vi, Título xv de la Recopilación de las Leyes de los reynos de las Indias. La promulgó Felipe III el 12 de mayo de 1619 y dice: "en algunas provincias de las Indias es muy frecuente la plaga de langosta, que infesta, y destruye los campos, y sembrados, y conviene buscar la semilla, que dexa debaxo de la tierra [...] Y encargamos a los Governadores el cuidado de hacer cavar, o arar la tierra, o echarle ganado de cerda, que descubra, y destruya la semilla antes que se aumente el daño". 
“más que en otras partes" porque cuando él estuvo allí, "vino tanta que, si no se pusiera el recaudo que se puso para matarla y destriparla, pusiera en grande trabajo aquella tierra" ${ }^{40}$ En 1518 , la expedición de Juan de Grijalva tuvo una desafortunada experiencia con la langosta en el transcurso de la batalla en Champotón. Dice el cronista que "mucho daño hizo a los nuestros haber langosta por aquellos pedregales, porque a veces entendían saltándoles con el vuelo, que era flecha, y la reparaban, y otras, que entendían que era langosta, los hería la flecha sin guardarse della". ${ }^{41}$

Diego de Landa nos deja una notas sobre una plaga de langosta que se puede ubicar hacia 1535, porque ocurrió cuando los españoles salieron de Yucatán y antes de que Montejo "el Mozo" sometiera la tierra; según estos datos se trata del tiempo que transcurrió entre la segunda y tercera etapa de la guerra de conquista. ${ }^{42}$ Dice el fraile que además de la falta de agua y del gasto sin control del maíz "en las guerras de los espańoles", "se les recreció la langosta por espacio de cinco años, que no les dejaba cosa verde". Todo esto convergió en "tanta hambre que se caían muertos por los caminos, de manera que cuando los espańoles volvieron no conocían la tierra aunque con otros cuatro años buenos después de la langosta, se había mejorado algo". Pudieron sobrevivir comiendo cortezas de los árboles, "en especial uno que llaman cumché, ${ }^{43}$ que es fofo y blando por dentro". ${ }^{44}$

Sobre este apunte de Landa hay algunos aspectos que se relacionan con los textos proféticos del katún 13 Ahau del Chilam Balam de

${ }^{40}$ Tomás López Medel, De los tres elementos, p. 51.

${ }^{41}$ Diego López de Cogollugo, Historia de Yucatán, p. 10.

${ }^{42}$ En 1526, Montejo consiguió la autorización para la conquista, que comenzó hacia 1527 por la costa oriental, y tuvo que abandonarla en 1529. La segunda etapa inició en 1530 hasta que en 1534 de nuevo los castellanos tuvieron que abandonar la península. La última y definitiva entrada fue en 1540 y se dio por finalizada en 1547, con la represión de la llamada "Gran Rebelión de los Mayas", Ma Isabel Campos Goenaga, "La llama divina”, p. 48.

${ }^{43}$ Árbol, 4.5 a 12 metros de alto, la madera muy blanda, el tronco que consiste en gran parte en médula; corteza lisa, gris. El tronco tiene almidón. Se llama "Bonete" en Yucatán, Campeche y Morelos; "kunch" o "kumchié" en maya yucateco. En aspecto exterior la fruta se parece a un gran pimiento verde no está desemejante de una pimienta verde grande. La carne es amarillo dulce y rojizo; se come cocinado o como ensalada y se hacen dulces, José Ramírez, "El Pileus heptaphyllus", pl. 41-45.

${ }^{44}$ Diego de Landa, Relación de las cosas, p. 25-26. 
Chumayel. García Quintanilla sugiere que hacia el año de 1539 terminó un katún 13 Ahau, lo que coincidiría con la fecha que se establece en Landa. Por otro lado, las tres primeras partes de la profecía dicen

1. Hambre tremenda trae su carga: de jícamas silvestres será el pan; durante cinco años bajan jícamas silvestres y frutos del árbol del ramón. ${ }^{45}$

2. Bajarán años de langosta, pan de langosta y agua de langosta:

3. Diez generaciones, trece generaciones de langosta tendrá su carga. ${ }^{46}$

Los dos primeros puntos no dejan duda respecto a la coincidencia en Landa, es más, habla de "cinco ańos" de hambre y Landa dice que la langosta "se les recreció por cinco años". El tercer punto denota un gran conocimiento de la langosta, de saak, por parte de los sabios mayas que registraban los eventos para tratar de adelantarse a ellos en un futuro. ${ }^{47}$ Como dice García Quintanilla, "por la calidad del saber respecto a saak", puede verse que en el ejercicio de "profetizar" habían sistematizado el saber sobre la naturaleza y sobre sus sociedades". ${ }^{48}$ Pero regresemos al punto tres. Ya se dijo que la Schistocerca piceifrons piceifrons produce dos generaciones por año, que multiplicadas por los 5 son las diez generaciones. Respecto a las trece generaciones, son las tres generaciones que necesita completar el insecto para pasar totalmente la fase solitaria y alcanzar la fase gregaria, mucho más virulenta y destructiva.

La familiaridad con saak'y cómo sustentarse en épocas de plaga es evidente. Por un lado están las jícamas, que como son tubérculos

${ }^{45} \mathrm{La}$ pulpa del fruto es comestible. Las semillas hervidas o tostadas tienen sabor parecido a las castañas y son muy nutritivas se comen solas o con maíz, miel y plátanos. Tostadas y molidas se usan como sustituto del café. Con las semillas se hace una harina negra usada para confeccionar pan o una especie de tortilla y también preparan un cocimiento que recomiendan para los convalecientes.

${ }^{46}$ Alejandra García Quintanilla, "Saak' y el retorno del fin del mundo”, p. 329.

${ }^{47}$ Cuando registraban estos acontecimientos lo hacían con una finalidad muy concreta ya que creían en la posibilidad de la repetición. Esta concepción seguía vigente en el siglo XviII cuando encontramos esta anotación: "Estoy en 18 de agosto de este ańo de 1766. Hubo tormenta de viento. Escribo su memoria para que se pueda ver cuántos años después va a haber otra", Libro del Chilam Balam de Chumayel, p. 149.

${ }^{48}$ Alejandra García Quintanilla, "Saak' y el retorno del fin del mundo”, p. 328. 
Cuadro 2. Plagas de langosta. Yucatán. Siglos XVI-XVII-XVIII-XIX

\begin{tabular}{llll}
\hline Siglo XVI & Siglo XVII & Siglo XVIII & Siglo XIX \\
\hline 1518 (mayo) $^{\mathrm{a}}$ & 1618 (junio 23) $^{\mathrm{d}}$ & $1710-1717$ & $1800-4$ \\
$1535-40$ & $1621-1631$ & $1755-56$ & \\
$1541-42^{\mathrm{b}}$ & $1692-93$ & 1761 &
\end{tabular}

$1552-53$

$1765-1774$

$1587-88^{c}$

$1590-1593$

Fuentes: Landa, Relación de las cosas; López de Cogolludo, Historia de Yucatán; López Medel, De los tres elementos; AGI, Contaduría, leg. 911-A y 911-B, "Cuentas de la real hacienda dadas por los oficiales reales de Yucatán, 1540-1650”; Cárdenas Valencia, 1937, 68; AGI, México, 369, "Obispo a la Corona, 18 abril de 1693"; Molina Hubbe, Las hambres de Yucatán; AGI, México 3054; AGI, México 3057, "Testimonio C. 2o"; AGI, Indiferente, 142, núm. 7 "Meritos y servicios P. Lizárraga, 1723"; AGNM, Intendentes, 75, "Gobernador al Virrey, 10 de agosto de 1800"; AA, Oficios y decretos, "Cabildo de Mérida al Obispo, 31 julio de 1804". a) En Champotón; b) en Mérida y Campeche; $c$ ) en Mocochá, Telchac, Kini, Tixpehual; d) en Mérida.

se desarrollan bajo tierra lo que las protege de la langosta, y por otro las distintas clases de árboles y frutas silvestres, como el ramón o el cumché, que forman parte de su manejo de la selva tropical y del paradigma ecológico que sustentaba a la civilización maya.

$\mathrm{Al}$ igual que en el apartado anterior, se elaboró el cuadro 2 en el que aparece un panorama para Yucatán en el que las plagas estaban presentes de manera constante, lo que hace pensar en el impacto a la producción agrícola y, en consecuencia, la escasez y carestía del alimento principal de la sociedad. Se pueden enfatizar cuatro grandes plagas: una en el siglo XVI entre 1587 y 1593 , otra en el XVII de 1621 a 1631, y dos en el siglo XVIII, la primera entre 1710 y 1717 y la segunda entre los años de 1765 y 1774 . Por otra parte, es de destacar los cinco ańos ya nombrados, entre 1535 y 1540 , y el último registro que corresponde al siglo XIX, entre 1800 y 1804.

Es necesario conocer la particularidad del sistema de milpa en Yucatán, sus tiempos y sus espacios para comprender en toda la extensión su dependencia del clima, y lo que supone para este ciclo agrícola la presencia de amenazas como huracanes (nortes, lluvias abundantes) y plagas de langosta. 


\section{FENÓMENOS NATURALES ADVERSOS Y CICLO AGRÍCOLA}

La milpa constituye un sistema agrícola que responde a las condiciones del suelo de la península, a su "errático" régimen pluvial y al clima húmedo que favorece el crecimiento de la vegetación y las plagas. Es un sistema extensivo y su producción es de temporal. Su explotación se basa en la roza, tumba y quema y se utiliza una técnica manual. Esto no lo convierte en un sistema de producción agrícola de subsistencia o autosubsistencia, ya que según investigaciones arqueológicas, fue el sistema que pudo sostener el desarrollo de las ciudades mayas del clásico (incluso antes) con el aumento demográfico y la especialización en el trabajo, por lo que la milpa debía producir excedentes para mantener a los diversos especialistas. Este sistema, es el que siguió predominando en la época colonial.

Se considera que la milpa es un sistema porque consta de actividades agrícolas y no agrícolas que se integran y complementan, porque en ella se concreta no solo la cuestión agrícola (tierra-cultivo-cosecha), sino que al constituirse en la principal forma de sustento de los mayas, toda su vida gira alrededor de ella y en este espacio el aspecto ideológico tiene un papel importante. La economía de milpa se fundamenta en muchos cultivos, en varios espacios y variedades de plantas y es el principal policultivo del área maya junto con el huerto o solar y el Pet Pach, un lugar en la milpa donde se cultivan agrupadas hortalizas de temporal. El principal policultivo es la milpa con la característica asociación mesoamericana de maíz, calabaza y frijol, "la santísima trinidad alimenticia" en la que el maíz es el principal producto y el centro del complejo cultural. En la milpa se cultivan especies que tienen diferentes ciclos de desarrollo: cortos y largos, con lo que aseguran productos a lo largo del año si las condiciones lo permiten. El espacio de milpa no suele ser demasiado grande y se manejan dos o tres al mismo tiempo. En cuanto a los tipos de milpa existen diferentes si se toma en cuenta el uso del monte: la primera vez que en un espacio se hace la roza, tumba y quema se considera milpa de primer año o "milpa de roza”, y la segunda vez que se siembra en esa misma área se llama "milpa de caña"; así que, aunque sólo se hiciese una nueva milpa de "roza" al año, siempre estaría la de "caña" del ciclo anterior. 
Cuando se relacionan los tiempos del ciclo agrícola y en el régimen de Yucatán puede establecerse un calendario que integre las épocas en que los eventos como los excesos de viento y agua, huracanes, sequías y plagas de langosta que son factores de riesgo, se convierten en una amenaza significativa para la los habitantes de la península y que se concrete en un desastre en forma de crisis agrícola o incluso crisis de subsistencia.

Veamos esos tiempos. La península de Yucatán tiene, climatológicamente hablando, dos periodos diferenciados, el de lluvias que transcurre de mayo a octubre, y la época seca entre noviembre y abril. En la época de lluvias regulares, éstas son de tipo tormenta y, en general, de precipitación abundante. En el norte y noreste de la península, las lluvias tienen una duración de dos y tres meses, aunque las precipitaciones son escasas. En el litoral del Golfo de México la lluvia es moderada y el mes más lluvioso es septiembre, por la influencia ciclónica. En la época de secas pueden darse algunas lloviznas asociadas con los nortes, pero los meses más secos son febrero, marzo y abril.

Entre agosto y octubre se selecciona y mide la parcela de monte, se establece el límite, hacen el contracerco y se limpia. También, aprovechando la humedad se desmonta y se tumban los árboles grandes (monte alto) con hacha, tarea que presenta dificultades si están secos. Las labores de desmonte (monte bajo) continúan hasta casi antes de la quema. Mientras, todo se pica y se esparce en la milpa para que se seque aprovechando los meses de más calor. Los meses de marzo, abril y, en ocasiones, parte de mayo se ocupan en la quema. Cuando se avecinan las primeras lluvias, pero todavía no llueve, se suele sembrar en seco el maíz de ciclo corto, el de grano pequeño. Con las primeras lluvias siembran el maíz de ciclo largo y grano grueso. De junio en adelante se deshierban las siembras adelantadas y cuando se establece el temporal, entre junio y agosto, se resiembra el maíz.

El veranillo de san Juan, sequía intraestival o canícula en términos meteorológicos, es la disminución en la cantidad de lluvia en plena época lluviosa, durante uno o dos meses. Ocurre en los meses de julio y agosto y si se prolonga esta escasez de lluvias, entonces se produce una sequía. 
Entre los meses de septiembre y octubre se dobla el maíz para evitar la humedad excesiva de las lluvias. En esta época el riesgo está en estos excesos de lluvia propia de la época, en ocasiones agravados por tormentas tropicales o huracanes, lo que añade a la amenaza el factor viento.

Entre noviembre y diciembre se cosecha el maíz de ciclo corto y en enero comienza el de ciclo largo, para finalizar en marzo. En esta época que las plantas están crecidas, la langosta se convierte en una amenaza para lograr la cosecha y se torna en un serio peligro entre abril y junio. En esos meses se realizaron las siembras anticipadas o siembras en seco, o bien las primeras siembras con las lluvias. Cuando comienzan a despuntar los brotes de maíz y existe plaga de langosta activa, se pierden. Ahora bien, si todavía no se ha establecido el temporal, puede volver a sembrarse allá por el mes de julio, pero la pérdida económica es importante aunque se dé la cosecha.

\section{Fenómenos NATURALES ADVERSOS Y SOCIEDAD}

Ya vimos el espacio social yucateco característico en la época colonial en el que uno de los principales componentes era la población indígena, bien por sí mismo o por su calidad de tributario. Además, las repúblicas de indios mantuvieron el control sobre los recursos naturales que explotaban para mantener a la sociedad colonial y entregar los excedentes de producción. Así, cualquier variación en la población indígena o en el número de tributarios afectaba intensamente al sistema colonial yucateco.

Tomaremos como ejemplo el siglo XVI para mostrar cómo se entrelazan todos los elementos que se han expuesto en este texto: fenómenos naturales adversos (exceso de agua, vientos, huracanes y plagas de langosta), sistema de milpa y, ahora, la población indígena de la que se observarán las oscilaciones. El ejercicio inicia en 1550 porque es la fecha en que se aplicaron las primeras tasaciones, y finaliza en 1601 porque culmina la primera etapa de descenso de tributarios. Un punto que siempre hay que tener en cuenta, es que un descenso en tributarios y mantas no implica, necesariamente, un descenso demográfico de la población indígena total o viceversa. Esto se debe a los 
CuAdro 3. Tributarios y poblacion indígena, Yucatán 1550-1601

\begin{tabular}{lrrr}
\hline & 1550 & 1586 & 1601 \\
\hline Tributarios & 57,644 & 50,000 & 48,125 \\
Población indígena & 230,576 & 170,000 & 163,625 \\
\hline
\end{tabular}

Fuentes: Manuela C. García Bernal, Yucatán, población y encomienda, 1978, 30-143; Manuela C. García Bernal, La sociedad de Yucatán, p. 29.

cambios que se producen en la variable del concepto de tributario y a los distintos factores de conversión de población que se aplican. ${ }^{49}$

Este periodo presenta dos momentos de descenso en el número de tributarios. El primero se sitúa entre las dos reformas del sistema tributario, 1550-1586, y supone aproximadamente 13 por ciento menos tributarios, en un lapso de 36 años. Ahora bien, este porcentaje no es muy elevado porque el concepto de tributario cambió entre estos ańos: en 1584 se amplió la base de tributarios al incorporar en la categoría de medios tributarios a viudos y viudas, solteros y solteras. ${ }^{50}$ Por ello, para establecer las dimensiones reales del descenso demográfico es necesario revisar las cantidades totales de población indígena, que arrojan una disminución de 26.27 por ciento en los mismos 36 ańos, es decir casi el doble del descenso en tributarios.

Esta etapa de retroceso se extiende hasta 1601, en que tanto tributarios como población total descendieron 3.75 por ciento con respecto a 1586, en 15 años. En total, en estos primeros 51 años los tributarios disminuyeron en 16.51 por ciento y la población total indígena en 29 por ciento.

Se puede obtener una visión más contextualizada que permita alguna explicación de este proceso, si se cruza la información de esta primera etapa de descenso con los registros de fenómenos naturales adversos, principalmente de origen físico y natural, que impactaron en Yucatán durante ese tiempo. En esta ocasión se incorporaran al análisis los registros sobre epidemias, hambres y sequías.

${ }^{49}$ Manuela Cristina García Bernal, Yucatán. Población y encomienda, pp. 70-78.

50 "Papeles relativos a la visita del oidor Dr. Diego García de Palacios, 1583", Boletín $A G N$, pp. 387-482. 
A lo largo del siglo xvi se hicieron presentes en el espacio yucateco distintos eventos de origen natural. Las sequías, la langosta, las epidemias, huracanes y el hambre incidieron de manera constante y, al conjugarse varios de estos fenómenos, el impacto en la sociedad rebasó, en ocasiones, su capacidad de asimilación y recuperación. Entonces se hicieron presentes las crisis agrícolas, demográficas o de subsistencia.

$\mathrm{Al}$ observar el cuadro 4, la presencia de plagas de langosta en años sucesivos (1535-1542, 1551-1553, 1587-1593) sólo puede explicarse por ser una especie endémica de la península y que tiene condiciones privilegiadas para desarrollarse. Los años de sequía pueden causar un desequilibrio en la producción agrícola y las necesidades alimenticias, y se agrava si la falta de lluvias o su escasez ocurren en ańos subsecuentes como en 1551-1552, 1559-1560, 1562-1565 o 1571-1576. Las fuentes proporcionan un registro de tres huracanes en esta época: 1552, 1561 y 1568. Por último, las epidemias son parte importante de las crisis, sobre todo si se trata de enfermedades como la viruela, que forman parte de lo que han dado en llamar "colonización bacteriana", y que afecta a gran número de población indígena.

Por sí mismas, la concreción de estas amenazas pone en peligro el equilibrio de la sociedad, pero si se presenta un encadenamiento de varias de ellas el desastre puede estar asegurado. Así, en esta parte del siglo Xvi destacan los ańos 1535-1539, en que como se mencionó líneas arriba, sequía, langosta y epidemia de viruela, junto con la escasez de maíz, agravada por la guerra y la incapacidad de obtener suministros vía el comercio por la misma situación, concluyeron en una hambruna que contribuyó al descenso inicial de población indígena.

El segundo momento diferenciado está entre los años de 1552 y $1553^{51}$ porque se concretaron sobre la península las amenazas de

${ }^{51}$ Casi todos los autores como Enrique Florescano, Espinoza, Nancy Farriss entre otros, toman la información de Molina Solís que a su vez es retomada por Molina Hübbe y Molina Font, que no revelan sus fuentes y asientan estos eventos en estos ańos. Por lo tanto, manejan que fue a partir de 1551 , o entre 1551 y 1552 . La fecha correcta es a partir de 1552 y 1553. Es posible, que el dato original se tomase del propio Tomás López Medel, que en verdad dice en su texto: "estando yo en la provincia de Yucatán el año de 1551 en la visita de aquella provincia, primero día de septiembre, vino un buracán”, pero el Oidor de la Audiencia de Guatemala cumplió su función de Visitador de la provincia 
Cuadro 4. Huracanes, sequías, plagas de langosta, epidemias y hambres. Yucatán, siglo XvI

\begin{tabular}{|c|c|c|}
\hline Fecha & Suceso & Fuente \\
\hline 1535 & $\begin{array}{l}\text { Escasez } \\
\text { Sequía } \\
\text { Plaga (langosta) } \\
\text { Hambre }\end{array}$ & $\begin{array}{l}\text { Molina Hübbe, 1941, 11-13 } \\
\text { Florescano, 1980, } 81\end{array}$ \\
\hline $\begin{array}{l}1535-40 \\
\text { (circa) }\end{array}$ & $\begin{array}{l}\text { Sequía } \\
\text { Plaga (langosta) } \\
\text { Hambre }\end{array}$ & $\begin{array}{l}\text { Landa, 1982, } 25 \\
\text { Farriss, 1992, } 108\end{array}$ \\
\hline 1536 & Epidemia (viruela) & Erosa Barbachano, Nov., 16 \\
\hline $1541-42$ & Plaga (Langosta) & López Cogolludo, 1957, 218, 221 \\
\hline 1544 & Epidemia (fiebre amarilla?) & Chamberlain, 1982, 236 \\
\hline $1551-52$ & $\begin{array}{l}\text { Sequía } \\
\text { Hambre } \\
\text { Carestía } \\
\text { Esterilidad }\end{array}$ & $\begin{array}{l}\text { Florescano, 1980, } 81 \\
\text { Molina Hübbe, 1941, 13-15 }\end{array}$ \\
\hline $\begin{array}{l}15521^{\circ} \\
\text { Septiembre }\end{array}$ & Huracán & López Medel, 1990, 33 \\
\hline $1552-53$ & Plaga (langosta) & López Medel, 1990, 51 \\
\hline 1553 & Hambre & $\begin{array}{l}\text { Lizana, 1893, C-1,9 } \\
\text { López Cogolludo, 1957, } 291\end{array}$ \\
\hline 1559 & Sequía & DDQAMY, II, 1938, 20-22 \\
\hline 1560 & Sequía & DDQAMY, II, 1938, 33 \\
\hline $\begin{array}{l}1561 \\
\text { (circa) }\end{array}$ & Huracán & $\begin{array}{l}\text { DDQAMY, } 1938,73-15,81,92 \text {, } \\
94,95,98,102\end{array}$ \\
\hline 1562 & Sequía & DDQAMY, II, 1938, 76, 78, 101 \\
\hline 1564 & Sequía & $\begin{array}{l}\text { AGI, Contaduría, leg. 911-A y 911-B, } \\
\text { "Cuentas de la Real Hacienda dadas por } \\
\text { los oficiales reales de Yucatán, } 1540- \\
1650 " \\
\text { Farriss, } 1992,108\end{array}$ \\
\hline 1565 & Sequía & DDQAMY, II, 1938, 331 y ss. \\
\hline 1566 & Epidemia & $\begin{array}{l}\text { AGI, México, 359, "Obispo a la Corona, } \\
18 \text { de Julio de } 1566 " \\
\text { Farriss, } 1992,108\end{array}$ \\
\hline
\end{tabular}


Cuadro 4. Huracanes, sequías, plagas de langosta, epidemias y hambres. Yucatán, siglo XVI (continuación)

\begin{tabular}{|c|c|c|}
\hline Fecha & Suceso & Fuente \\
\hline 1568 & Huracán & García Acosta,1992, 28 \\
\hline $1569-70$ & $\begin{array}{l}\text { Epidemia (fiebre amarilla, } \\
\text { viruela) }\end{array}$ & Molina Solís, 1904-1913, 1, 114-115 \\
\hline 1571 & $\begin{array}{l}\text { Epidemia (viruela, fiebre } \\
\text { amarilla) } \\
\text { Escasez } \\
\text { Hambre } \\
\text { Sequía }\end{array}$ & $\begin{array}{l}\text { Erosa Barbachano, Nov., } 16 \\
\text { Molina Hübbe, 1941, 14-16 } \\
\text { Florescano, 1980, } 81\end{array}$ \\
\hline 1571 & $\begin{array}{l}\text { Escasez } \\
\text { Hambre }\end{array}$ & López Cogolludo, 1957, 335 \\
\hline $1571-72$ & $\begin{array}{l}\text { Sequía } \\
\text { Escasez }\end{array}$ & $\begin{array}{l}\text { AGI, Contaduría, leg. 911-A y 911-B, } \\
\text { "Cuentas de la Real hacienda 1571-1572" } \\
\text { Farriss, 1992, } 108\end{array}$ \\
\hline $1571-72$ & Epidemia (fiebre amarilla) & Góngora Bianchi, 2000, 302 \\
\hline 1573 & Epidemia (viruela) & Quezada, 1995, 239 \\
\hline $1575-76$ & $\begin{array}{l}\text { Epidemia } \\
\text { Sequía } \\
\text { Escasez } \\
\text { Hambre }\end{array}$ & $\begin{array}{l}\text { Molina Solís, 1904-1913, 1, } 166 \\
\text { AGI, Contaduría, leg. 911-A y 911-B, } \\
\text { "Cuentas de la Real hacienda 1576" } \\
\text { Farriss, 1992, } 108\end{array}$ \\
\hline 1577 & Epidemia (influenza o gripe & Erosa Barbachano, Nov., 20 \\
\hline 1580 & $\begin{array}{l}\text { Epidemia (sarampión y } \\
\text { tabardillo) }\end{array}$ & Quezada, 1995, 239 \\
\hline $1587-88$ & Plaga (langosta) & $\begin{array}{l}\text { AGI, Contaduría, leg. 911-A y 911-B, } \\
\text { "Cuentas de la real hacienda dadas por los } \\
\text { oficiales reales de Yucatán, 1540-1650", }\end{array}$ \\
\hline 1590 & $\begin{array}{l}\text { Plaga (langosta) } \\
\text { Epidemia (sarampión y } \\
\text { tabardillo) }\end{array}$ & $\begin{array}{l}\text { AGI, Contaduría, leg. 911-A y 911-B, } \\
\text { "Cuentas de la real hacienda dadas por los } \\
\text { oficiales reales de Yucatán, 1540-1650" } \\
\text { Quezada, } 1995,239\end{array}$ \\
\hline $1592-93$ & Plaga (langosta) & $\begin{array}{l}\text { AGI, Contaduría, leg. 911-A y 911-B, } \\
\text { "Cuentas de la real hacienda dadas por los } \\
\text { oficiales reales de Yucatán, 1540-1650" }\end{array}$ \\
\hline
\end{tabular}


huracán, plaga de langosta y sequía. Los precios del maíz fueron al alza, estaba a 12 reales en $1552^{52}$ y "por espacio de seis meses" 53 hubo "mucha hambre en toda la tierra" ${ }^{54}$ Esta es la primera gran confluencia de eventos después de que terminó la conquista militar. En esta época, el oidor López Medel llevaba a cabo su visita y junto a los franciscanos inició la congregación de pueblos. Por estas circunstancias, muchos indígenas escaparon del control colonial a las zonas de refugio. Así, parte del descenso de la población y tributarios puede atribuirse a estos acontecimientos.

Una tercera coyuntura se revela al inicio de los ańos setenta. El huracán de 1568 y la epidemia de 1569 prepararon el camino a ella. La sequía apareció entre 1571 y 1572, y en esta precisa circunstancia hay que hablar del "hambre" que aparece en los documentos normalmente asociada a los eventos anteriores o como consecuencia de ellos. Pero ahora, el hambre apareció como consecuencia, en primera instancia, de una amenaza no natural sino algo tan humana como la búsqueda de riqueza. En esta ocasión, la situación crítica provino de que la "grandísima falta de maíz en esta tierra, con que se padeció gran hambre [...] no fue la causa de esta desdicha la esterilidad de la cosecha, sino haberse sacado grandes cantidades de maíz para fuera de esta tierra". Fue tal la extracción, que para abastecer a la provincia, el gobernador tuvo que informarse en que lugares había y "por mar y tierra" traer el necesario para el abasto. ${ }^{55}$ En

entre el 13 de junio de 1552 hasta 1553, por lo que el huracán debió ocurrir el 1 de septiembre de 1552, su nombramiento e instrucciones están en AGI, México, 3018, "Nombramiento e instrucciones al Licenciado Tomás López, Oidor de la Audiencia de Guatemala, para la visita de las provincias de Yucatán, Cozumel y Tabasco. Santiago de Guatemala, 9 de enero de 1552", en $D H Y$, I, pp. 16-18.

Por otro lado, el hambre que los mismos autores ubican a partir de 1551, por las mismas razones hay que ubicarla, por lo menos, a partir de 1552, si no es que en 1553 . Esta confusión quizás se puede explicar porque dos de los cronistas que registran esta "hambre" manejan una fecha diferente. Así, fray Bernardo de Lizana la ubica en 1552, mientras que fray Diego López de Cogolludo dice que fue en 1553 "en el tiempo que se edificaba" el convento de Izamal.

${ }^{52}$ Luz María Espinosa Cortés et al., Cronología de hambrunas, p. 80; Virginia García Acosta et al., Desastres agrícolas en México, p. 108.

${ }^{53}$ López de Cogolludo, Historia de Yucatán, p. 291.

${ }^{54}$ Lizana, Historia de Yucatán, C1, 9, cap. viII.

${ }^{55}$ Diego López de Cogolludo, Historia de Yucatán, p. 335. 
este tiempo, los mayas que no murieron de hambre, se fueron a los montes en busca de alimentos. Si a lo anterior se le suma que las epidemias estuvieron presentes desde 1569 hasta 1577, sólo con el año de 1544 libre de enfermedad, o al menos no hay fuente que así lo indique, la década de los setenta fue una de las peores del siglo Xvi. Para el resto del periodo, si pensamos en que la plaga de langosta era una constante y que las epidemias hicieron repetidas apariciones, entonces puede comprenderse el descenso de tributarios.

\section{Apuntes finales}

Durante los siglos de dominación colonial incidieron regularmente en el espacio yucateco diversos fenómenos naturales adversos. Esta presencia respondía tanto a la ubicación geográfica de la península como a sus características físicas y climáticas. Esto por sí mismo no suponía ningún evento crítico, pero relacionados con el ciclo agrícola peninsular se transformaron en desastres.

Para la sociedad yucateca colonial, esta presencia de fenómenos como huracanes o plagas de langosta, y su concatenación con otros como sequías y epidemias, impactaba en la estructura de dominación colonial. En tanto sociedad preindustrial, su base agraria la hacía vulnerable a los fenómenos naturales y la mantenía en constantes crisis agrícolas y de subsistencia donde la escasez y carestía del maíz resultaban en graves periodos de hambre.

Además, el funcionamiento del sistema colonial dependía de las repúblicas de indios, cualquier contexto que significara la huida o muerte de la población maya significaba una disminución en la matrícula de tributarios, que laceraba al sistema sustentado en formas compulsivas para el trabajo y extracción de riqueza: tributo, servicio personal y repartimientos.

El ejercicio que realizamos con la segunda mitad del siglo XVI muestra como, al incluir la variable de fenómenos adversos en el análisis del descenso de tributarios experimentado en esa época, se amplía el margen explicativo para entender el proceso, dejando de lado cualquier tipo de determinismo. 


\section{BiBLIOGRAFÍA}

Ancona, Eligio, Historia de Yucatán desde la época más remota hasta nuestros días, 5 vols., Mérida, Ediciones de la Universidad de Yucatán, 1978.

Barrera Marín, Alfredo, "El manejo de las selvas por los mayas: sus implicaciones silvícolas y agrícolas", en Biótica, 2, 2, 47-61.

Barrera VÁzquez, Alfredo y Silvia Rendón, El Libro de los libros del Chilam Balam, México, FCE, 1979.

Barrientos Lozano, Ludivina et al., Manual técnico sobre la langosta voladora (Schistocerca piceifrons piceifrons Walker, 1870) y otros acridiodeos de Centro América y sureste de México, San Salvador, FAO-OIRSA, 1992, 24-47.

Beriain, Josetxo, La lucha de los dioses en la modernidad. Del monoteismo religioso al politeismo cultural, Barcelona, Anthropos, 2000.

Boletin del Archivo General de la Nación, tomo Ix, núm. 4, México, 1938.

Bracamonte y Sosa, Pedro y Gabriela Solís Robleda, Espacios mayas de autonomía. El pacto colonial en Yucatán, Mérida, Universidad Autónoma de Yucatán, 1996.

Buj Buj, Antonio, "Les plagues de llagosta. Algunes reflexions sobre una calamitat no tan natural", en Cuaderns Agraris, 28, Barcelona, septiembre 2003, 5-19.

Campos Goenaga, Ma Isabel, "Conciencia mágica vs. Fatalismo: mayas y espańoles de la península de Yucatán durante la colonia. Dos formas de percibir el riesgo y concebir los desastres", en Campos Goenaga y De Giuseppe, coords., La cruz de maíz. Politica, religión e identidad en México entre la crisis colonialy la crisis de la modernidad, México, ENAH-INAH (en prensa).

, "La llama divina: procesos e informaciones sobre idolatrías en Yucatán (1552-1562)", Tesis de licenciatura, México, ENAH, 1993.

Cárdenas Valencia, Francisco de, Relación historial eclesiástica de la provincia de Yucatán de la Nueva España, escrita el año de 1639, México, Antigua Librería Robredo de José Porrúa e Hijos, 1937. 
Carmagnani, Marcello, Alicia Hernández y Ruggiero Romano, Para una historia de América I. Las estructuras, Fideicomiso Historia de las Américas. Serie Américas, México, FCE-Colmex, 1999.

Ciudad Real, Antonio de, Tratado curioso y docto de las grandezas de la Nueva España, o relación breve y verdadera de algunas cosas de las muchas que sucedieron al padre fray Antonio Ponce en las provincias de la Nueva España siendo comisario general de aquellas partes, México, unam, 1976.

Chamberlain, Robert S., Conquista y colonización de Yucatán, 1517-1550, México, Porrúa, 1982.

Diccionario de Motul, México, UnAM, 1984.

Documentos para la Historia de Yucatán. Primera Serie 1550-1560 (DHYI), France V. Scholes, recopilador, publicados por Carlos R. Menéndez, Mérida, Tipografía Yucateca, 1936.

Don Diego Quijada Alcalde Mayor de Yucatán, 1561-1565 (DDQA$M Y$ ), France V. Scholes y Eleanor B. Adams, eds., Biblioteca Histórica Mexicana de Obras Inéditas, 14 y 15, 2 vols., México, Antigua Librería Robredo de José Porrúa e Hijos, 1938.

Erosa Barbachano, Arturo, "Historia de las epidemias en Yucatán” en Medico Moderno, noviembre, 14-26.

Espinosa Cortés, Luz María, Fabiola Rueda Arroniz y Rosa María Andrade, Cronología de hambrunas en México 40000 AC1985 DC, Serie Historia del Hambre en México, anexo 2, México, Instituto Nacional de la Nutrición, 1987.

FARriss, Nancy M., La sociedad maya bajo el dominio colonial. La empresa colectiva de supervivencia, Madrid, Alianza editorial, 1992.

Fernández de Oviedo, Gonzalo, Historia General y Natural de las Indias, Madrid, Biblioteca de Autores Españoles, 1959.

Florescano, Enrique, coord., Análisis histórico de las sequias en México, México, Secretaría de Agricultura y Recursos Hidráulicos, Comisión del Plan Nacional Hidráulico, 1980.

García Acosta, Virginia, "Enfoques teóricos para el estudio histórico de los desastres naturales", en Virginia García Acosta, coord., Estudios históricos sobre desastres naturales en México, México, Ciesas, 1992. 
, "Una vista al pasado. Huracanes y/o desastres en Yucatán” en Revista de la Universidad Autónoma de Yucatán, núm. 223, cuatrimestre de 2002, 3-15.

García Acosta, Virginia, Juan Manuel Pérez Zevallos y América Molina del Villar, Desastres agrícolas en México. Catálogo Histórico. Tomo I. Épocas prehispánica y colonial, (958-1822), México, FCE, Ciesas, 2003.

García Bernal, Manuela Cristina, La sociedad de Yucatán, 17001750, Sevilla, EEHA/CSIC, 1972.

Población y encomienda en Yucatán bajo los Austrias, Sevilla, EEHA/CSIC, 1978.

García Quintanilla, Alejandra, "Saak' y el retorno del fin del mundo. La plaga de langosta en las profecías del katún 13 Ahau”, en Ancien Mesoamérica, 16, Cambridge University Press, 2005, 327-344.

GarZa Urbina, Enrique, "La langosta schistocerca piceifrons piceifrons y su manejo en la planicie huasteca”, http://www.oeidrusportal.gob.mx/oeidrus_slp/modulos/bilioteca/.

Góngora-Biachi, Renán A., "La Fiebre Amarilla en Yucatán durante las épocas precolombina y colonial", en Rev Biomed, 11, 2000, 301-307. http://www.uady.mx/ - biomedic/revbiomed/ pdf/rb001149.pdf.

Hernández Xolocotzi, Efraím, "La agricultura en la península de Yucatán”, en Xolocotzia. Obras de Efraim Hernández Xolocotzi, tomo I, Revista de Geografía Agrícola, Universidad Autónoma de Chapingo, 371-409.

"Incorporación a la Real Corona de las encomiendas de la provincia de Yucatán. Distritos de las Reales Cajas de Mérida y Campeche", Boletín del Archivo General de la Nación, Ix, México, 1938. 456-469.

"Instrucciones de la Audiencia de México a Gaspar Juárez de Ávila, México 22 agosto de 1550", José Rubio Mañé, Archivo de la historia de Yucatán I, México, SRI, 1942.

KonRad, Herman W., "Fallout of the wars of the chacs: the impact of hurricanes and implications for the pre-Hispanics Quintana Roo Maya Processes" en Marc Thompson et al., eds., Status, 
Structure, and stratification: current archaeological reconstructions, Calgary, University of Calgary, 1985, 321-330.

,"Caribbean tropical storm. Ecological Implications for the pre-Hispanic and contemporary Maya subsistence practices on the Yucatan Peninsula", en Revista Mexicana del Caribe, I, 1996, 98-130.

Landa, Diego de, Relación de las cosas de Yucatán, México, Porrúa, 1982.

Las Casas, Bartolomé de, Historia de las Indias, 3 vols., México, FCE, 1965.

Libro del Chilam Balam de Chumayel, México, Conaculta, 1998.

Lizana, Bernardo de, Historia de Yucatán: devocionario de Nuestra señora de Izamal y conquista espiritual, México, Imprenta del Museo Nacional, 1893.

López de Cogolludo, Diego, Historia de Yucatán, 2 vols., México, Editorial Academia Literaria, 1957.

López Medel, Tomás, De los tres elementos. Tratado sobre la naturaleza y el hombre del Nuevo Mundo, Madrid, Alianza Editorial, 1990. Mendíz Bolio, Antonio, El libro del Chilam Balam de Chumayel, Mérida, Maldonado ed., s/f.

Molina Font, Gustavo, La tragedia de Yucatán, México, editorial Jus, 1941.

Molina HüBbe, Ricardo, Las hambres de Yucatán, México, Orientaciones, 1941.

Molina Solís, Juan Francisco, Historia de Yucatán durante la dominación española, 3 vol., Mérida, Imprenta del Estado, 1904-1913.

Olcina Cantos, Jorge y Javier Martín Vide, La influencia de clima en la historia, Madrid, Arco/Libros S.L., 1999.

Ortiz, Fernando, El huracán: su mitología y sus símbolos, México, FCE, 1947.

"Papeles relativos a la visita del oidor Dr. Diego García de Palacios, 1583", en Boletín del Archivo General de la Nación, XI, 1940, 387-482.

Peniche Moreno, Paola, Tiempos aciagos. Las calamidades y el cambio social del siglo XVIII entre los mayas de Yucatán, Colección Peninsular, México, Ciesas, Porrúa, 2010. 
Pérez Toro, Augusto, "La agricultura milpera de los mayas de Yucatán”, en Enciclopedia Yucatanense, vol. vI, México, Editorial yucatanense, Editorial oficial del gobierno de Yucatán, 1977.

Piña Chan, Román y Patricia Castillo Peña, Tajín. La ciudad del dios Huracán, México, FCE, 1999.

Popol Vuh, México, FCE, SEP, 1984.

Quezada, Sergio, "Epidemias, plagas y hambres en Yucatán, México (1520-1700)", en Rev. Biomédica, 6, 1995, 238-242.

Ramirez, José, "El Pileus heptaphyllus", Naturaleza II, 3, 707-711, 41-45.

Recopilación de Leyes de los Reynos de las Indias, Edición facsimilar que se corresponde con la edición príncipe Julián Paredes 1681, 4 vols., más 1 vol. de estudios, Madrid, Miguel Ángel Porrúa, Escuela Libre de Derecho, México, 1987.

Relaciones Histórico Geográficas de la Gobernación de Yucatán (RHGY), 2 vols., México, unam, 1983.

Roys, Ralph L., F. Scholes y E. Adams, "Census and Inspection of the Town of Pencuyut, Yucatán, in 1583 by Diego García de Palacio, Oidor of the Audiencia of Mexico" en Ethnohistory, VI, 1959, 195-225.

Sánchez de Aguilar, Pedro, Informe contra idolorum cultores del obispado de Yucatán, México, Antigua Librería Navarro.

Scholes, France V. y Ralph Roys, Los Chontales de Acalan-Tixchel, edición Mario Humberto Ruz, traducción M.H. Ruz y Rosario Vega, México,unam, iIf, Cem y Ciesas, 1996.

Sierra O’Reilly, Justo, Los indios de Yucatán, tomo i, Mérida, UADY, 1994.

Terán, Silvia y Christian H. Rasmussen, La milpa de los mayas, Mérida, Talleres gráficos del sudeste S.A. de C.V. 1994.

"Genetic diversity and agricultural strategy in 16th century and present-day Yucatecan Milpa Agriculture", en Biodiversity and Conservation 4, 1995, 363-381.

Terán, Silvia, Christian Rasmussen y Olivio May, Las plantas de la milpa entre los mayas (Etnobotánica de las plantas cultivadas por campesinos mayas en las milpas del noreste de Yucatán, México), Mérida, Fundación Tun Ben Kin, A.C., 1998. Consultado 
en http://www.mayas.uady.mx/exposiciones/exp_04.html. Thompson, Philip C., Tekantó: a Maya Town in Colonial Yucatan, Tulane, Tulane University, Middle American Research Institute, 2000.

VArgas, Ernesto, Itzamkanac y Acalan. Tiempos de crisis anticipando el futuro, México, IIA/Unam, 2001.

Wilches-Chaux, Gustavo, "La vulnerabilidad global" en Los desastres no son naturales, Andrew Maskrey, comp., Bogotá, LA RED, ITDG, 1993, 9-50.

Zavala, Silvio, La encomienda indiana, México, Ed. Porrúa, México, 1973.

, El servicio personal de los indios de la Nueva España I, 15211550, México, El Colegio de México, El Colegio Nacional, 1984.

Fecha de RECEPCión del artículo: 6 de junio de 2011 FECHA DE ACEPTACIÓN Y RECEPCIÓN DE LA VERSIÓN FINAL: 18 de agosto de 2011 